\title{
Investigation of Garhs / Hill forts (fortress) using Geo-Informatics Tools in District Pauri of Garhwal Himalaya
}

\author{
Nagendra Singh Rawat \\ Department of History and Archaeology, HNB Garhwal University,Srinagar, Garhwal 246174
}

\begin{abstract}
One of the most redeeming archaeological feature in Garhwal Himalaya is the ruins of a well laid out regular stone structure of large buildings or fortresses located on the highest cliff of the mountain locally known as Garhs belonging to late medieval. It is owing to the presence of such structures of Garh, this region, which was earlier known as Kedarkhnad in ancient times (Dabral, 1961), was christened as Garhwal from 15th century onward. Chatak, 1990; Naithani, 2006 Dhasmana(1995). Though some preliminary studies have been done by various workers to provide insight into the architecture and history of these Garhs, however no serious investigations has been done to locate them in the region and study these structures in historical perspective. Though the well known Chandpur Garh was excavated by archaeological Survey of India in 2004 to know its antiquity (report unpublished). However, these late medieval structures have largely rather remained a subject of curiosity and not worth of any academic study, and hence have not attracted the attention of to the scholars and others till today. In view of this, I have taken up the study of Garhs in a Geo-historical perspective through multidisciplinary approach to understand the emergence of such structures during late medieval phase and their spatial distribution in the specific mountainous topography. However the present paper reports the preliminary results of the study to precisely find the location of the Garhs in Pauri district of Garhwal Himalaya through exhaustive field work, Remote Sensing and Google Earth.
\end{abstract}

\section{Introduction and Problem}

The history of the Garhwal Himalaya after the decline of Katyuris around $12^{\text {th }}$ century AD and the emergence of Pal dynasty in $16^{\text {th }}$ century is very sketchy and not much is known of this period (Dabral,1961; Katouch,1996; Gairola, 1943; Rawat, 2002; Handa, 2002). According to Negi (2007) After Katyuries, the region of Garhwal was ruled by about 64 independent petty chieftains who frequently fought with each other. However, in the beginning of 16th century, Ajaypal, Chieftain of Chandpur Garhi unified the whole region of Garhwal. After Katyuri dynasty these Garhadhipatis played a vital role in history of Garhwal. It is believed that during this intervening phase these medieval structures were raised in the Garhwal Himalaya by the petty ruling feudal chiefs, but strangely enough no historical information is available about these feudal chiefs who independently ruled the fragmented territories of Garhwal. The only remnants of this phase are the ruins of their forts or Garhs which supposedly were strategically raised on the highest cliff as the military outpost to keep a watch over the invaders. Therefore besides this information, these structures have not only remained elusive but even the location of a large number of structures is still conjectural and uncertain in this region.

While investigating the Garhs based on these accounts, what is intriguing to note that the location of the Garhs indicated in the publication has not been clearly shown and incomplete to precisely reach to the site of these structures for further investigations? Therefore, to undertake the exploration of these late medieval structures, a new scientific methodology based on Survey of India maps, Remote Sensing and Goggle Earth has been used in locating the sites of Garhs in inaccessible areas in Garhwal Himalaya. Although archaeology poses a unique challenge to Remote Sensing due to various factors and constraints but scientist and archaeologist in recent years have been successful in detecting the buried structure or camouflaged features. With the help of these virtual investigation tools Vega (2011) discovered about 140 Hill forts in Central coast of Peru in South America. Further advances have been made by using LIDAR (Laser based remote Sensing Technology) to detect the buried archaeological structure (Chase et. al 2012). Recently in Indian context the spatial and non-spatial information retrieved from historical maps, paintings etc of stone fortress of Chitledoorg in Central Karnataka in India has been integrated and studied using the Geo-informatics and Virtual Reality tools to study the change in the landscape over a period of time (Nalin and Rajani, 2012). Therefore, in view of the importance of these Garhs in Garhwal Himalaya, this paper focus on the result of preliminary investigation using remote sensing data and field survey in district pauri Garhwal to trace the remains of Garhs in district Pauri garhwal. 


\section{Review of work:}

The published literature on this particular phase of Garhwal History is limited, Atkinson (1884) touched this topic 'as in the days of Ajay pal, Garhwal was divided in 52 small units each chief of these units were fully independent. Later on many authors put the only passing reference about these Garhs. Alam Singh Rana (1910), Walton (1927), Vaishnava(1927), Raturi (1928), Dabral (1976,77), Bahuguna (1995) ,Chauhan (1997), Handa (2002)refers about these Garhs as Baoni Garhi . It was Raturi (1928) in his book Garhwal ka itihas gave the list of 52 Garhs. According to Raturi (1928) these Garhs were initially strong hold of Khasias. Later on this were captured by adventurer Aryan warrior properly known as Thakurs. Negi (1988) provides the list of 64 Garhs, Katouch (1996) gave lists of more than hundred Garhs, and secondly some other individual enthusiastic published their paper about Garhs in journals and local magazines. In this context a reference may be made of a special volume of a regional magazine 'APARAJITA'in 2008 which was fully devoted on the Garhs of Garhwal Himalaya. It provided some basic information on the types and location of Garh in Garhwal Himalaya. Excepting this work, there is no detailed work on these late mediaeval structures in historical perspective. It is quite possible that due to the inaccessibility in the rough terrain of the mountains, a large number of historical structures or Garhs have not been investigated or explored by workers and hence these structures have been left in oblivion.

\section{Study Area}

In order to find the location of the Garhs, a new strategy and method based on Geo-informatics tools of GPS, GIS and Remote Sensing, Google earth and field survey as indicated above has been used in the present study of the Pauri district of Garhwal (29045' to 30015' Latitude and 78024' to 79023'Longitude), falling in the North West flank of Uttarakhand encompasses an area of $52302 \mathrm{~km}$. In the present study two well know Garh of Chaundkot garh and Chhetra garh in Block Pokhra have been taken for detailed study. This district is surrounded by the districts of Chamoli, Rudraprayag and Tehri Garhwal in North, Bijnor \& Udhamsingh Nagar in South, Almora Nainital in East and Dehradun and Haridwar in West (Figure 1).

\section{Methodology}

Ancillary information on the location of Garhs was collected from different books and published literature. Locations of Garhs are identified by using SOI Toposheets (1:50.000) and traced by using high resolution satellite data (Quick bird and IKONOS).Vector (Point) layer of traced locations is prepared by using ERDAS IMAGINE 2011 software. IRS 1C LISS III satellite data is georeferenced using 16 Ground Control Points extracted from toposheets. It is used for making location map of different Garhs in the area. For understanding the rugged topography of the area, Slope (Figure: 2), Contours (Figure: 3) and Elevation zones map (Figure: 4) are prepared with the help of ASTER derived DEM (Figure: 5) using ESRI ArcGIS 10.1 software. Chaundkot Garh in Block Pokhra of Pauri district is marked using LISS III satellite data using different band combination(Figure:6) for enhanced identification of the Garh.

Finally the field survey of two important Garhs (1-Chaundkot Garh and 2- Chhetra Garh) has been done to study the ruins and the environmental background and to discern its architecture. It is Important to point out that Chaundkot Garh is mentioned in all three list of Garhs given by various workers but Chhetra Garh is not include in any of list. So for confirmation these two Garhs were surveyed with GPS (Global Positioning System) to mark its location.

Chaundkot Garh $\left(29^{\circ} 58^{\prime} 42.02^{\prime \prime N} 78^{\circ} 54^{\prime} 04.31^{\prime \prime E}\right)$ situated in near village Dantha, Patti Kimgidi Gad, Block Pokhra, near to Chaubattakhal, and Chhetra Garh $\left(29^{\circ} 53^{\prime} 05.29^{\prime \prime} \mathrm{N} 78^{\circ} 53^{\prime} 00.76^{\prime \prime E}\right)$ is situated near village Bansai, Patti Talai, Block Pokhra. The nearest station is KunajKhal in District Pauri Garhwal.

\section{Results:}

In the present study of the medieval structures of Garh shown in the three list as given by different scholars have been examined to check their location in the toposheet and find their signatures on the satellite imageries as mentioned above. Since the names of some Garhs in the three different list differ with each other giving different locations for similar Garhs and therefore, it is difficult to find a uniform number of such structures in the map. The study has revealed that there are some new location of Garhs which have been identified which does not find reference in any of the three list provided by the scholars. Secondly it is very important to highlight that the structures of square rooms with stone walls and surrounding ditches of Chhetra Garh which have been found buried and covered under dense bushes or forest cover over a large area does not show any signature on Google earth imageries but only some topographical features are discernable (figure: 7). In view of this it has been decided to make use of some high resolution satellite imageries or LIDAR (Laser based remote sensing technology) to develop this work further so that the structural remains buried under the thick vegetation or forest cover could be delineated through LIDAR. 
After visiting the site of Chhetragarh a large number of square structures made of stone or rock slabs have been found. On detailed examination of the structures it was estimated that there could be about more than 100 rooms which are clearly visible on one flank of top of the hill. Each room is almost square in shape measuring about $3 \mathrm{~m}$ long and $3 \mathrm{~m}$ wide (figure: 8 ). The other portion of the Garh is totally buried.(figure: 9). The peripheral main area of the Garh has been found surrounded with some unplanned stone wall running over the top of the cliff of two hills. The security of the Garh was further reinforced with 5 manmade ditches running between each two hill tops.

In second case the satellite imageries of fortified area of Chaundkot garh is very clear and the remnants of architectural pattern of the stone structure are found on the two hill top (which has been named as hill top -1 and 2) with many ditches around it (figure: 10). On the basis of this result it may be said that the hill top 1 was the place of chieftain or Nobel class (figure: 11) and the hill top 2 must have been a residential area for army (figure: 12). The total numbers of rooms at Chaundkot Garh could be more than 200. The remains of major rooms are also visible on the imagery which were seen also during the field survey (figure: 13) and there are 14 deep manmade ditches between these two hill tops, (figure: 14) two another manmade ditches are southern side of hill top 1 .

It is important to notice that these Garhs were highly protected as it were protected through natural ditches on one side and or through made ditches from two sides (figure: 15), and from another side the river or revaluate gives protection to it. The location of Garhs on the top of the hills or cliff overlooking the valley does show that they were made purely as warfare strategy to protect from the invaders but it will not be correct to assume these were purely the outpost however these were also raised for residential complex for the Chieftains as well as for their army and such represented the centre of power of the noble class who ruled in a particular area.

\section{Conclusion:}

With respect to prospecting for fortifications in this whole region, this case study demonstrates the feasibility, in terms of time and logistical-efficiency of using fine spatial resolution imagery that is freely available for viewing in Google Earth. It is possible to identify more locations using satellite imagery in Google Earth. This paper gives a detail account of Garh of Pauri Garhwal, however it is must be noted that the maximum number of medieval Garhs mentioned in list 1 are located in district pauri with very large topographical differences (from 609 meters to 2120 meters). Based on the result it has been possible to identify 14 main Garhs(list:1 ) referred in the published work, 7 new location of Garhs (list: 2) were identified while about 15 possible new location(list: 3 ) have been identified. The present preliminary scientific study of Garhs/Hill fortress of Uttarakhanad Himalaya does open a new avenue for the application of Geoinformatics technique in History and Archaeology.

\section{Acknowledgement}

The present work is part the $\mathrm{PhD}$ dissertation and therefore the research scholar is thankful to the HNB Garhwal University for providing me the fellowship to undertake my PhD work. I am also thankful to the Department of History including Ancient Indian History, Culture and Archaeology for providing me the necessary facilities to conduct my research work. Secondly I am very thankful to Dr. M.M.Kimothi (Director of Uttarakhand Space Application Center) who provide me the facility of satellite data for this work and Mr. Saurabh Purohit and Mr.Govind Singh Negi of U-SAC are also helped me to identifying these Garhs and to make the maps.

\begin{tabular}{|l|l|l|l|l|}
\hline S.N. & Name of Garh & \multicolumn{1}{|c|}{$\begin{array}{c}\text { Coordinates } \\
\text { Latitude, Longitude }\end{array}$} & $\begin{array}{c}\text { Elevation } \\
\text { in Mtrs. }\end{array}$ & Nearest Settlement \\
\hline 1. & Ban Garh & $\begin{array}{l}29^{\circ} 46^{\prime} 57.73^{\prime \prime} \mathrm{N} \\
78^{\circ} 56^{\prime} 55.13^{\prime \prime} \mathrm{E}\end{array}$ & 1670 & Bangarh Village \\
\hline 2. & ChaundKot Garh & $\begin{array}{l}29^{\circ} 58^{\prime} 42.02^{\prime \prime} \mathrm{N} \\
78^{\circ} 54^{\prime} 04.31^{\prime \prime} \mathrm{E}\end{array}$ & 2052 & Dantha Village \\
\hline 3. & Deval Garh & $\begin{array}{l}30^{\circ} 13^{\prime} 13.90^{\prime \prime} \mathrm{N} \\
78^{\circ} 51^{\prime} 36.80^{\prime \prime} \mathrm{E}\end{array}$ & 1041 & Bughani Village \\
\hline 4. & Dhangu Garh & $\begin{array}{l}30^{\circ} 04^{\prime} 02.39^{\prime \prime} \mathrm{N} \\
78^{\circ} 29^{\prime} 43.02^{\prime \prime} \mathrm{E}\end{array}$ & 609 & Kaudiyala \\
\hline 5. & Garhkot Garh & $\begin{array}{l}29^{\circ} 53^{\prime} 12.02^{\prime \prime} \mathrm{N} \\
78^{\circ} 42^{\prime} 18.01 \mathrm{E}\end{array}$ & 881 & Satpuli \\
\hline 6. & Kanda Garh & $\begin{array}{l}30^{\circ} 11^{\prime} 57.16^{\prime \prime} \mathrm{N} \\
78^{\circ} 41^{\prime} 51.59 \mathrm{E}\end{array}$ & 1410 & Dehalchauri \\
\hline 7. & Kolli Garh & $\begin{array}{l}29^{\circ} 49^{\prime} 28.69 " \mathrm{~N} \\
78^{\circ} 52^{\prime} 52.27^{\prime \prime} \mathrm{E}\end{array}$ & 1519 & Kalwari village \\
\hline
\end{tabular}


Investigation of Garhs / Hill forts (fortress) using Geo-Informatics Tools in District Pauri of Garhwal

\begin{tabular}{|l|l|l|l|l|}
\hline 8. & Langoor Garh & $\begin{array}{l}29^{\circ} 55^{\prime} 08.85^{\prime \prime} \\
78^{\circ} 39^{\prime} 21.88^{\prime \prime} \mathrm{E}\end{array}$ & 1857 & Gumkhal \\
\hline 9. & Lod Garh & $\begin{array}{l}29^{\circ} 51^{\prime} 46.01 " \mathrm{~N} \\
79^{\circ} 00^{\prime} 14.04 " \mathrm{E}\end{array}$ & 1819 & Shaitul Khal \\
\hline 10. & Mahab Garh & $\begin{array}{l}29^{\circ} 52^{\prime} 40.74^{\prime \prime} \mathrm{N} \\
78^{\circ} 27^{\prime} 18.62^{\prime \prime} \mathrm{E}\end{array}$ & 1642 & Hathi Mattha \\
\hline 11. & Nayal Garh & $\begin{array}{l}301106.40 \mathrm{~N} \\
784839.25 \mathrm{E}\end{array}$ & 913 & Nayal Village \\
\hline 12. & Rani Garh & $\begin{array}{l}30^{\circ} 04^{\prime} 04.36 " \mathrm{~N} \\
78^{\circ} 42^{\prime} 50.29^{\prime \prime} \mathrm{E}\end{array}$ & 2120 & Kanskhet \\
\hline 13. & Sabli Garh & $29^{\circ} 54^{\prime} 33.27^{\prime \prime N}$ & 1681 & Nandakhet \\
& & $79^{\circ} 01^{\prime} 03.44^{\prime \prime} \mathrm{E}$ & 2064 & Khirsu \\
\hline 14. & Ulkha Garh & $\begin{array}{l}30^{\circ} 09^{\prime} 33.78^{\prime \prime N} \\
78^{\circ} 50^{\prime} 53.92^{\prime \prime} \mathrm{E}\end{array}$ & & \\
\hline
\end{tabular}

List-1: Identified Garhs from list of Main (52) Garhs

\begin{tabular}{|l|l|l|l|l|}
\hline S.N. & Name of Garh & \multicolumn{1}{|c|}{$\begin{array}{c}\text { Coordinates } \\
\text { Latitude, Longitude }\end{array}$} & $\begin{array}{c}\text { Elevation } \\
\text { in Mtrs. }\end{array}$ & Nearest Settlement \\
\hline 1. & Chhetra Garh & $\begin{array}{l}29^{\circ} 53^{\prime} 05.29^{\prime \prime} \mathrm{N} \\
78^{\circ} 53^{\prime} 00.766^{\prime \prime} \mathrm{E}\end{array}$ & 2005 & Bansai Village \\
\hline 2. & Gahad Garh & $\begin{array}{l}30^{\circ} 13^{\prime} 10.46^{\prime \prime} \mathrm{N} \\
78^{\circ} 49^{\prime} 56.69^{\prime \prime} \mathrm{E}\end{array}$ & 918 & Gahad Village \\
\hline 3. & Ghugti Garh & $\begin{array}{l}29^{\circ} 57^{\prime} 00.26^{\prime \prime} \mathrm{N} \\
78^{\circ} 20^{\prime} 25.266^{\prime \prime} \mathrm{E}\end{array}$ & 1311 & Kasani Village \\
\hline 4. & Gurad Garh & $\begin{array}{l}29^{\circ} 56^{\prime} 25.03^{\prime \prime} \mathrm{N} \\
78^{\circ} 50^{\prime} 18.15 \mathrm{E} \mathrm{E}\end{array}$ & 1370 & Gurad Talla Village \\
\hline 5. & Khaira Garh & $\begin{array}{l}293637.02 \mathrm{~N} \\
784319.04 \mathrm{E}\end{array}$ & 874 & Kala Garh \\
\hline 6. & Rajja Garhi & $\begin{array}{l}29^{\circ} 49^{\prime} 59.35^{\prime \prime} \mathrm{N} \\
78^{\circ} 47^{\prime} 15.83^{\prime \prime} \mathrm{E}\end{array}$ & 1934 & Taadkeshwer \\
\hline 7. & Thandar Garh & $\begin{array}{l}30^{\circ} 3^{\prime} 48.39^{\prime \prime} \mathrm{N} \\
78^{\circ} 53^{\prime} 38.25^{\prime \prime} \mathrm{E}\end{array}$ & 1230 & Markhola Village \\
\hline
\end{tabular}

List-2: Identified Garhs From list of other mentioned Garh

\begin{tabular}{|l|l|l|l|l|}
\hline S.N. & Name of Garh & \multicolumn{1}{|c|}{$\begin{array}{c}\text { Coordinates } \\
\text { Latitude, Longitude }\end{array}$} & $\begin{array}{c}\text { Elevation } \\
\text { in Mtrs. }\end{array}$ & Nearest Settlement \\
\hline 1. & Dobar Garh & $\begin{array}{l}294641.53 \mathrm{~N} \\
784912.78 \mathrm{E}\end{array}$ & 1714 & Sandhan dhar \\
\hline 2. & Bairagarh & $\begin{array}{l}300355.72 \mathrm{~N} \\
782230.59 \mathrm{E}\end{array}$ & 444 & Gyuntha \\
\hline 3. & Bandargarh & $\begin{array}{l}293826.49 \mathrm{~N} \\
783541.61 \mathrm{E}\end{array}$ & 761 & Gujarvali Sot \\
\hline 4. & Bhagmal garh & $\begin{array}{l}295345.40 \mathrm{~N} \\
782207.26 \mathrm{E}\end{array}$ & 1036 & Gardkot \\
\hline 5. & Buragarh & $\begin{array}{l}294100.62 \mathrm{~N} \\
785744.60 \mathrm{E}\end{array}$ & 1310 & Chaibara \\
\hline 6. & Chilgarh & $\begin{array}{l}301322.82 \mathrm{~N} \\
784139.06 \mathrm{E}\end{array}$ & 624 & Kandi \\
\hline 7. & Garh & $\begin{array}{l}301301.73 \mathrm{~N} \\
785006.52 \mathrm{E}\end{array}$ & 890 & Basoli \\
\hline 8. & Ghindiyal garh & $\begin{array}{l}301344.25 \mathrm{~N} \\
785855.98 \mathrm{E}\end{array}$ & 2091 & Chipalghat \\
\hline 9. & Jamangarh & $\begin{array}{l}294455.00 \mathrm{~N} \\
783250.69 \mathrm{E}\end{array}$ & 824 & Grastinganj \\
\hline 10. & Jaspal garh & $295259.67 \mathrm{~N}$ & 1043 & Jaurasi malla \\
\hline 11. & Julamgarh & $\begin{array}{l}294107.06 \mathrm{~N} \\
785445.59 \mathrm{E}\end{array}$ & 1173 & Dala \\
\hline
\end{tabular}


Investigation of Garhs / Hill forts (fortress) using Geo-Informatics Tools in District Pauri of Garhwal

\begin{tabular}{|l|l|l|l|l|}
\hline 12. & Maba garh & $\begin{array}{l}295240.18 \mathrm{~N} \\
782726.08 \mathrm{E}\end{array}$ & 1630 & Amaldar ka gaun \\
\hline 13. & Nayangarh & $\begin{array}{l}300835.25 \mathrm{~N} \\
785608.91 \mathrm{E}\end{array}$ & 1692 & Chaluni \\
\hline 14. & Raja Garh & $\begin{array}{l}294009.99 \mathrm{~N} \\
785855.01 \mathrm{E}\end{array}$ & 1232 & Baniagaon \\
\hline 15. & Ranagarh & $\begin{array}{l}300318.69 \mathrm{~N} \\
782904.95 \mathrm{E}\end{array}$ & 599 & Jhair bada \\
\hline
\end{tabular}

List-3: Name of Villages with title of Garh

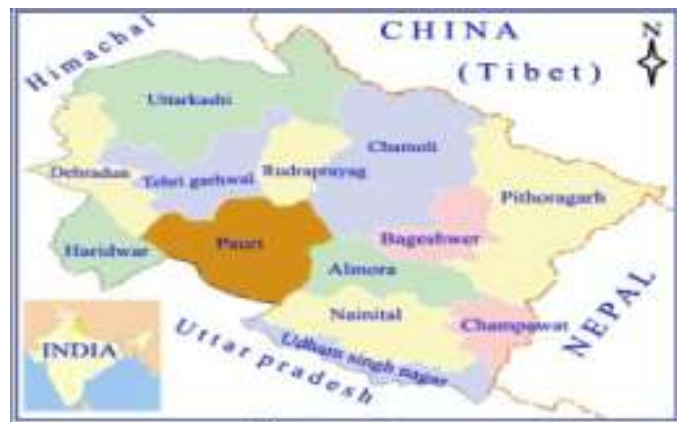

Figure: 1
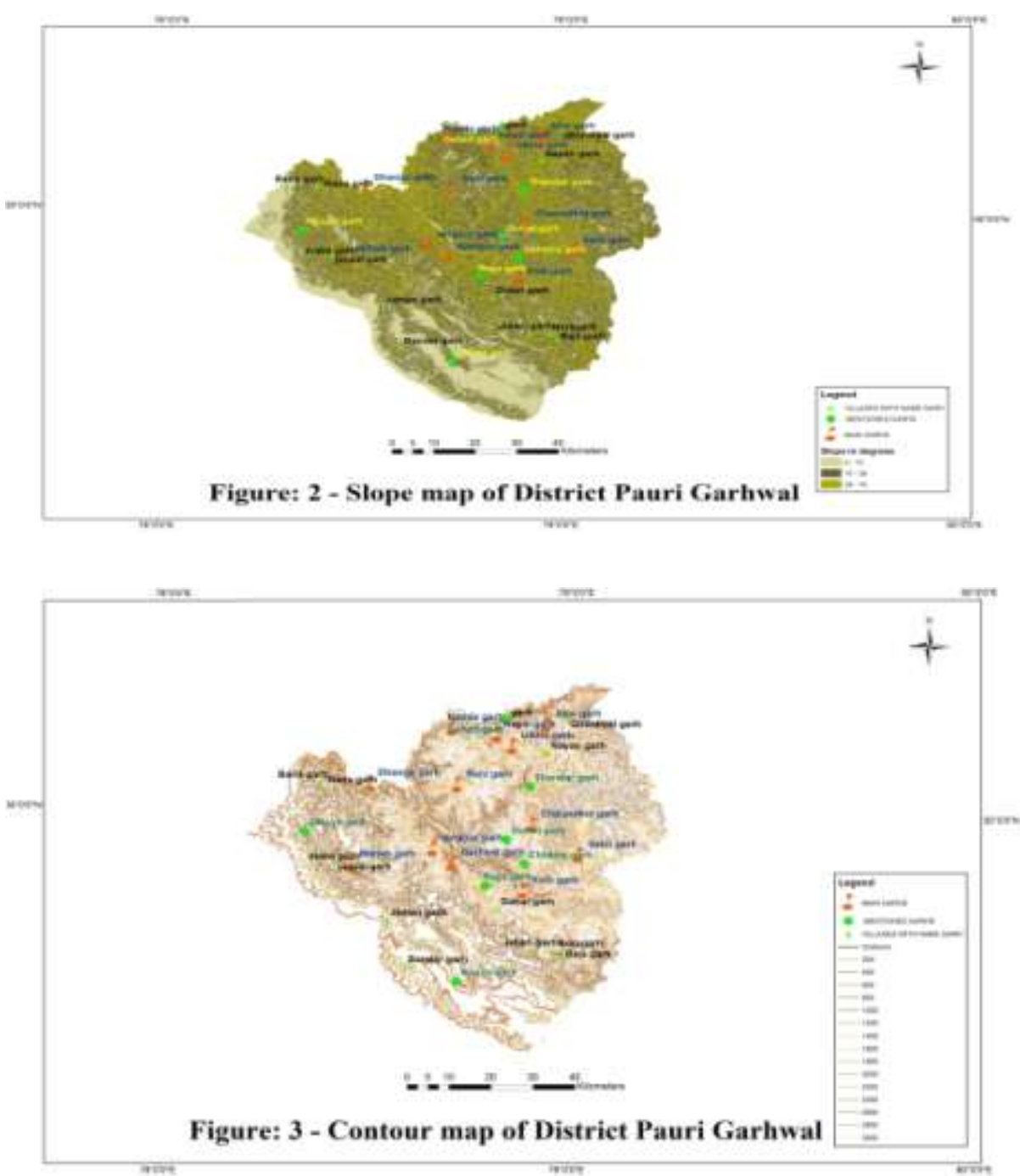

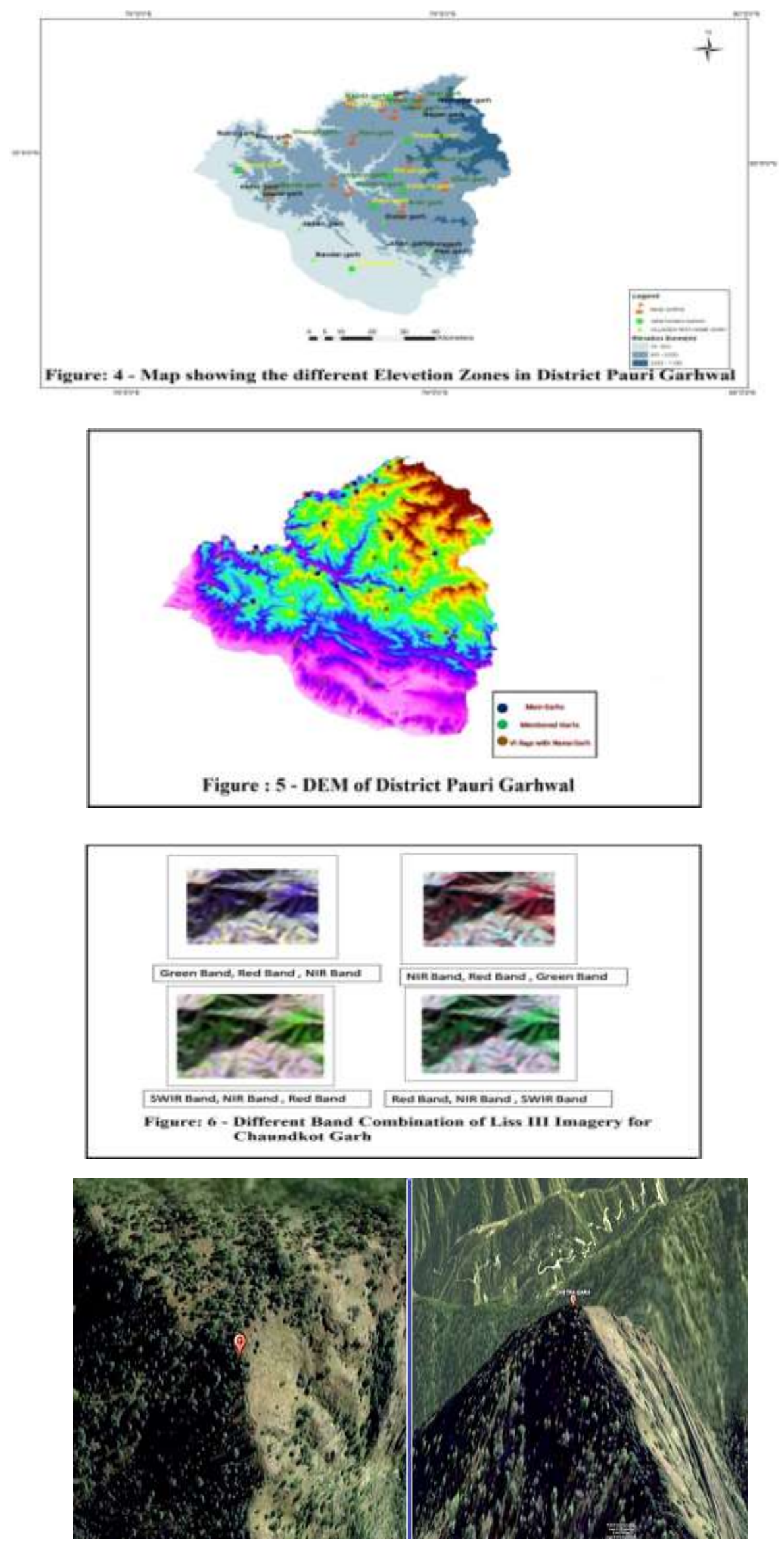

Figure: 7- View of Chhetra garh 


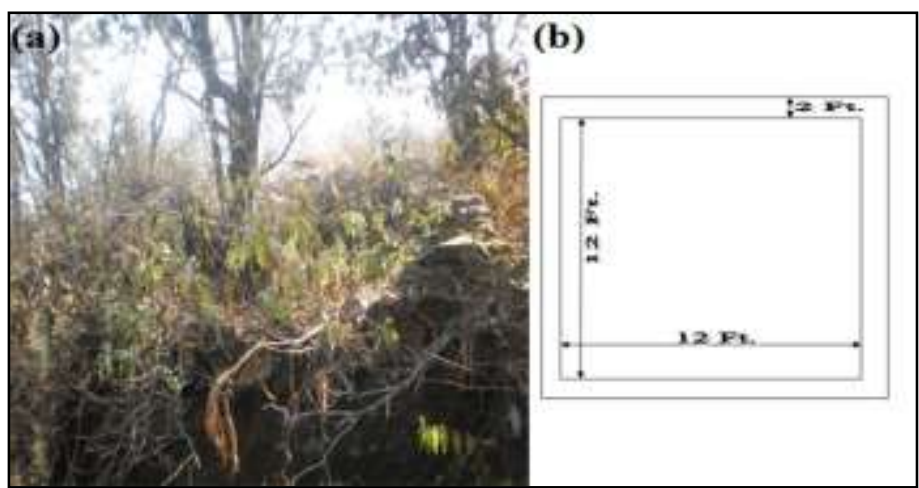

Figure: 8 (a) Ruminants of rooms at Chhetra Garh

(b) Measurement of rooms of Chhetra garh

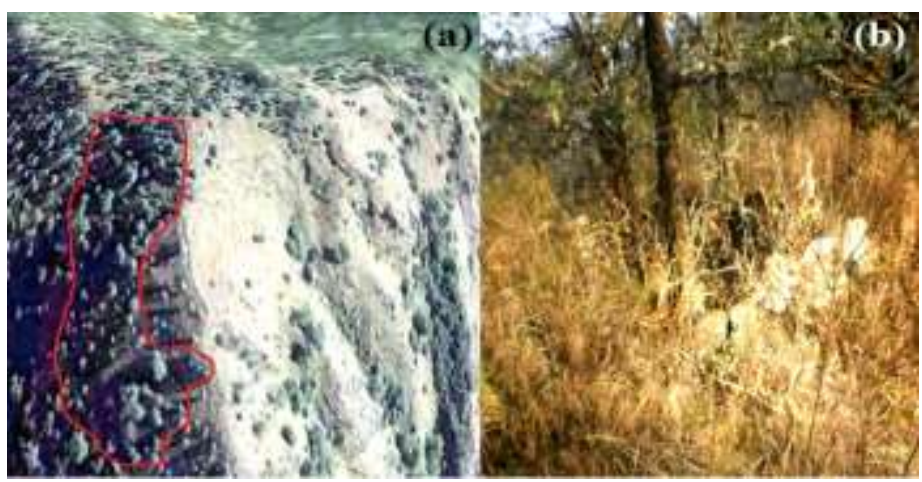

Figure : 9-(a)Google earth image of Chhetra Garh showing the covered area of site. (b)Photograph of a wall in covered area of Chhetra Garh.

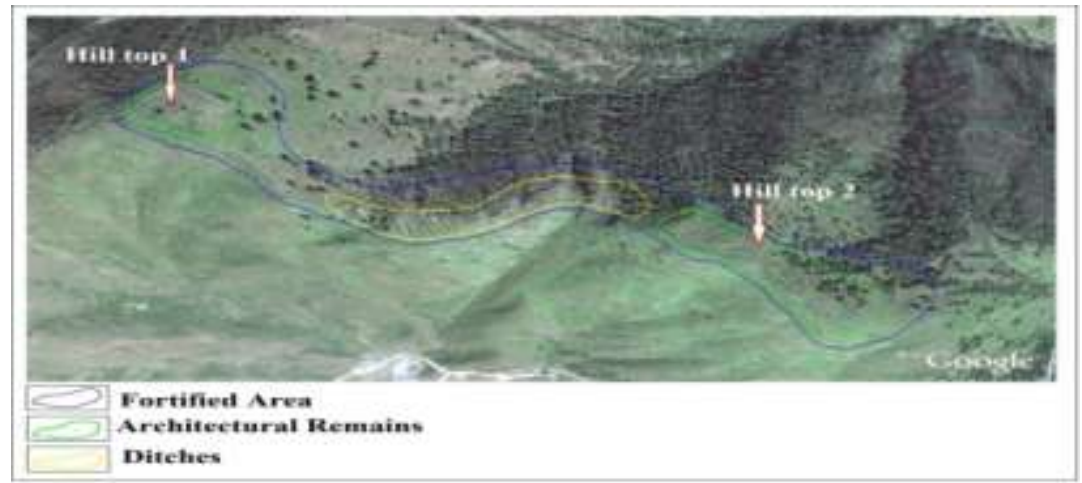

Figure : 10- Satellite view of ChaundKot Garh

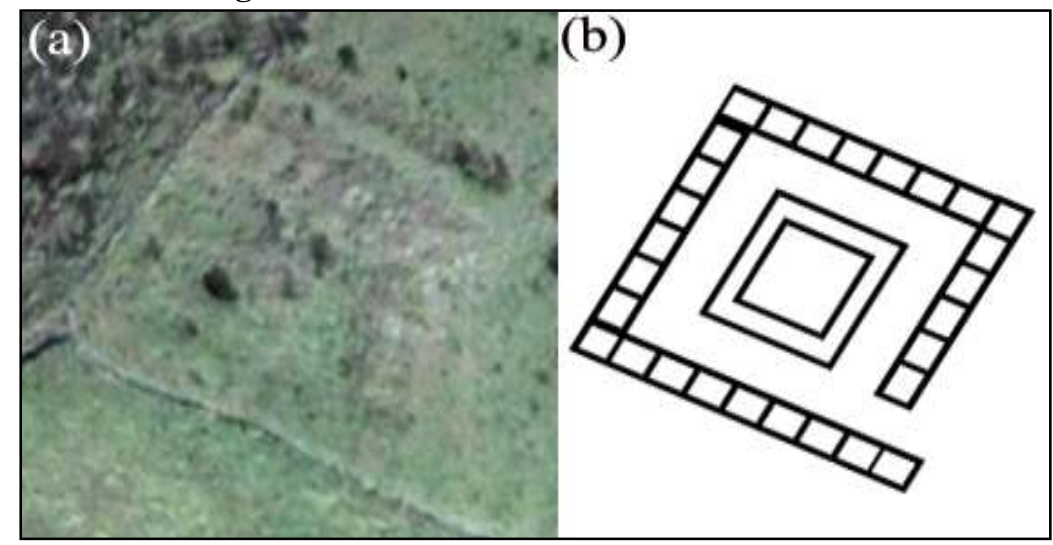

Figure : 11- (a) Satellite view of ruminants of rooms on hilltop 1. (b) Probable sketch of pattern of rooms on hilltop 1. 


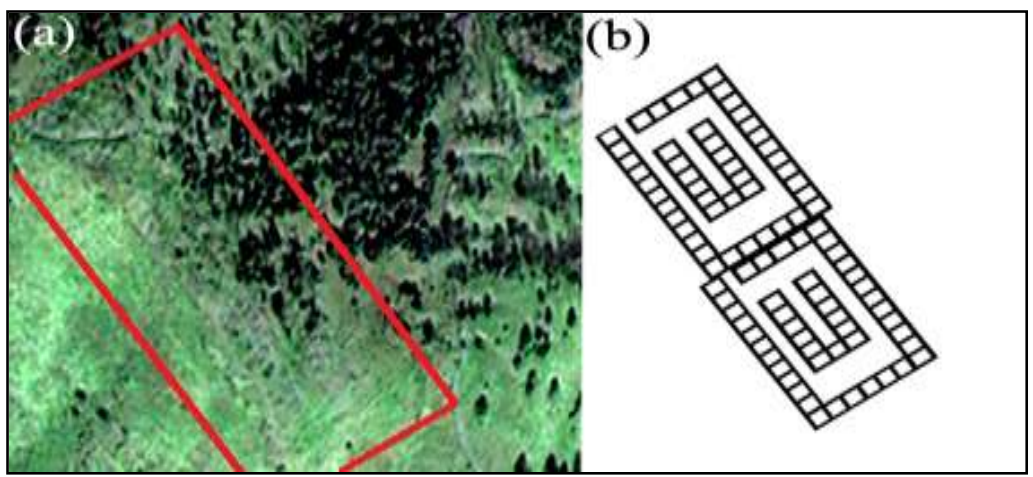

Figure : 12- (a)- view of ruminants of rooms on hilltop 2.

(b)- Probable sketch of pattern of rooms on hilltop 2.

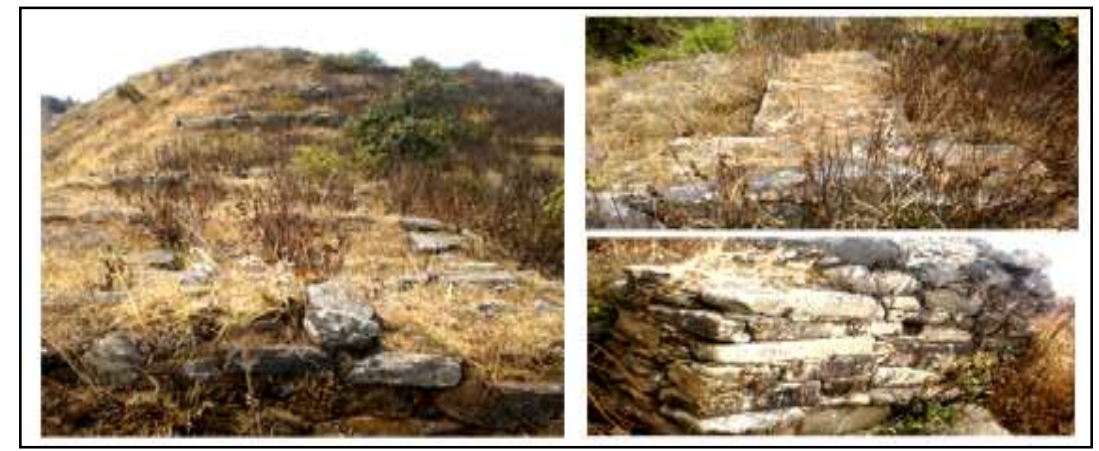

Figure : 13 - Photographs of ruminants of rooms at Chaundkot Garh

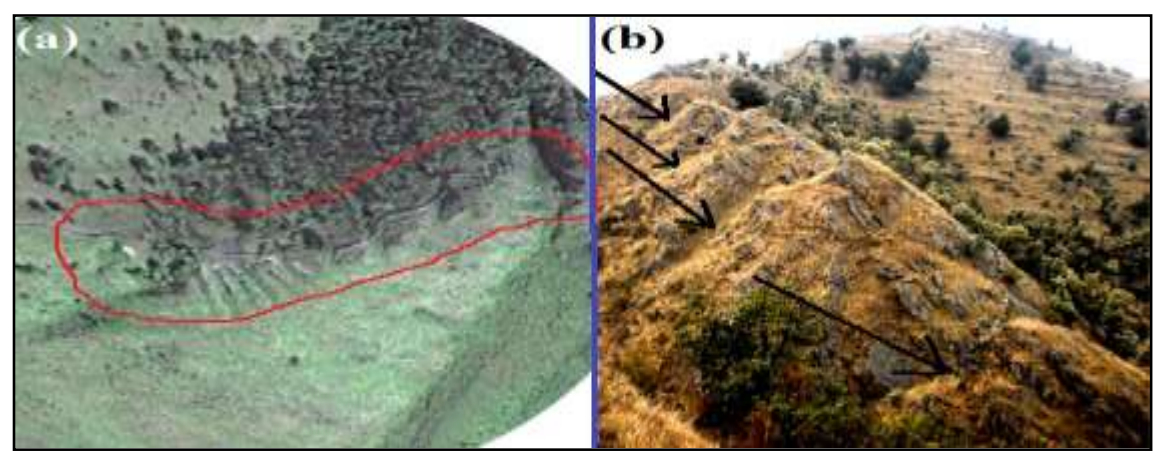

Figure : 14 (a) - signatures of ditches on Google Earth imagery (b)- Field photograph of Ditches at Chaundkot Garh

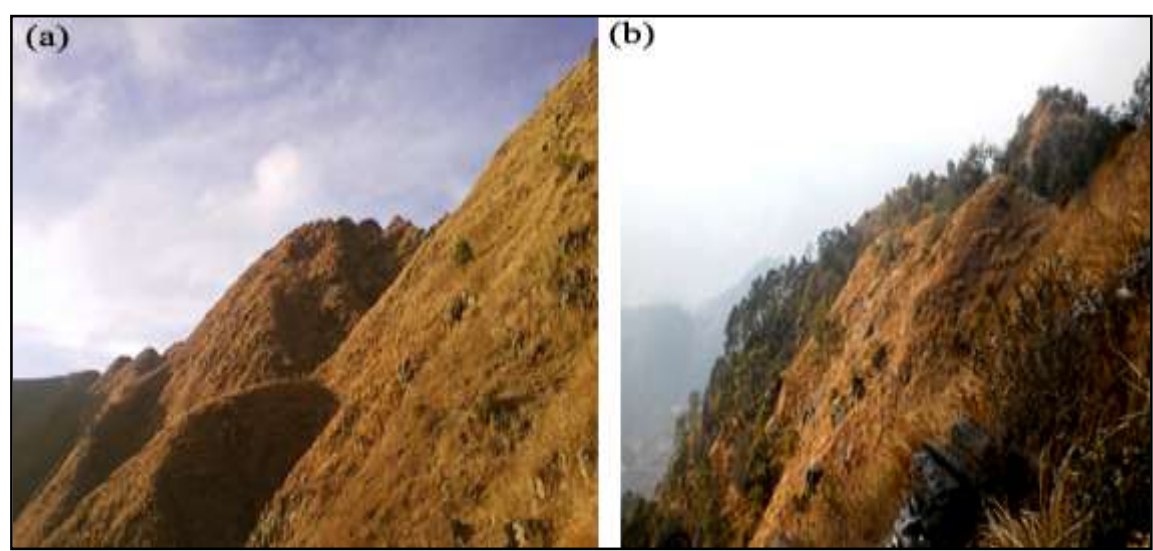

Figure: 15 (a) View of Natural ditch at Chaundkot Garh (b) View of natural ditch at Chhetra Garh 


\section{References:}

[1] Adrian Myers;2010; World Camp Delta, Google Earth and the ethics Of Remote sensing in archaeology; Archaeology Vol. 42(3) Pp. 455-467

[2] Atkinson E.T. (1884). The Himalayan Gazetteer, vol. II, III. Cosmo Publication, Delhi (Reprint 1973).

[3] Arlen F. Chase, Diane Z. Chase, Christopher T. Fisher, Stephen J. Leisz, and John F. Weishampel;2012;Geospatial revolution and remote sensing LiDAR in Mesoamerican archaeology Published online July 16, 2012,

[4] Bahuguna, M.R.(1995). Garhrajya Shasan ki Yadein, Samaya Prakashan.

[5] Brown Vega, M. , Nathan, C. and Gerbert, A. L. (2011), Ground Truthing of Remotely Identified Fortifications on the Central Coast of Peru. Journal of Archaeological Science 38(7):Pp 1680-1689.

[6] Chauhan, S. S. (1997). Garhwal ka Rajnetik Itihas,

[7] Dabral, S.P. (1967-90). Uttarakhand ka Itihas vol. I to XIII; Virgatha Prakashan Dogadda.

[8] Dhasmana M.M,1995; Perception of Bhutas in Garhwah in Primal Elements : The Oral Tradition Vol. 1; Edited by Saraswati Baidyanath ; Indira Gandhi National Centre for the Arts, New Delhi.

[9] Handa, O.C. (2002). History of Uttaranchal, Indus Publishing Company, New Delhi.

[10] Jason Ur, 2003;University of Chicago Oriental Institute, 1155 E. 58th St., Chicago, IL 60637 (j-ur@uchicago.edu) Received 11 July 2002; Revised 16 January 2003

[11] Katouch, Y. S.( 1996). Madhya Himalaya part-I : sanskriti ke pad chinha, Bhagirathi prakashan. Pp116-138.

[12] Khanduri, B.M. and S.S. Negi, (2007) Uttarakhand : A historical profile; dept of history, ancient Indian history, culture \&archaeology and museum of Himalayan archaeology and ethnography; HNBGU, Srinagar(Garhwal) Uttarakhand.,Page-52.

[13] Naithani, S.P. (2006). Uttarakhand ka Sanskritik Itihas Part-I; Pavetri Prakashan.

[14] Nalini N.S., Rajani M.B. (2012),Stone fortress of Chitledroog : visualizing old landscape of Chitradurga by integrating spatial information from multiple sources, Current Science Vol. 103, No.4.25, Pp. 381-387.

[15] Negi, S.S. (1988). Madhya Himalaya ka Rajnitik evam Sanskritik Itihas. Vani Prakashan Delhi

[16] Raturi, H.K. (1928,1980,). Garhwal ka Itihas, Bhagirathi prakashan Tehri.Pp154-157.

[17] Rana, A. S. Garhwal ka Bhugol (Geography of Garhwal).

[18] Rosa Lasaponara \& Nicola Masini; 2012; Satellite Remote Sensing:A New Tool for rchaeology; Springer Dordrecht Heidelberg London New York.

[19] Tomoya G.at al. 2009; 22nd CIPA Symposium, October, Kyoto, Japan, Pp. 11-15.

[20] Walton, H.G. (1927). The British Garhwal Gazetteer, Government press Allahabad. 